\title{
Enron And Continental Vending: A Comparison
}

Ronald M. Mano, (Email: RMANO@weber.edu), Weber State University

Matthew L. Mouritsen, (Email: mmouritsen@weber.edu), Weber State University

W

e have all heard it said that if we don't learn from history, we are condemned to repeat it. It appears that we, as the accounting profession, failed to learn from the Continental Vending case that occurred about four decades ago and thus repeated our mistakes in the Enron case. First, we will give a brief review of the basics of the Continental Vending case since few of us seem to remember it.

Quoting directly from Montgomery's Auditing, $10^{\text {th }}$ edition, copyright 1984:

This case was a criminal action against the auditors of Continental Vending for having made a false and misleading statement under the 1934 Act by having inappropriately issued an unqualified opinion. A major issue was the wording of the disclosure, in a footnote to the financial statements, of loan transactions involving the audited company, an affiliate, and an officer of the company. The government contended that the disclosure was inadequate because it did not state that amounts receivable from the affiliate were uncollectible at the balance sheet date nor did it specify the nature of the collateral, which was shares of the client's own stock. The auditors' defense was that the statements were in compliance with GAAP, which they maintained, indicated that they had not intended to deceive. The judge instructed the jury, however, that the critical test was whether the financial statements, as a whole, fairly presented the company's financial position and results of operations. Following those instructions, the jury found the defendants guilty.

The case was appealed to the second circuit which refused to reverse the decision. The major issue in the appellate decision written by Judge Friendly was whether the auditors had acted in good faith in not disclosing information that they were aware of but that was not required by GAAPessentially in the form of published authoritative pronouncements-to be disclosed.

\subsection{What We Should Have Learned From Continental Vending}

It seems clear to these authors that the lesson that the profession should have learned almost four decades ago was that when we state "fairly presented...in accordance with Generally Accepted Accounting Principles" we are making two statements rather than one statement. However, that is not how the profession seems to have been using that statement. It appears that the profession has believed that as long as we can somehow shoehorn our presentation into GAAP, we can claim fair presentation regardless of how unclear and difficult to understand that it might be to the lay reader.

\subsection{One Of The Author's Personal Experiences}

When I (Mano) was in Lincoln, Nebraska, while working on my Ph.D. I obtained a copy of the annual report of Con Agra Corporation. Con Agra is an agribusiness corporation headquartered in Omaha, Nebraska. The company was audited by what was then Coopers \& Lybrand (now PricewaterhouseCoopers) and their auditors' opinion was included in the annual report. It was a standard "unqualified" opinion which purports that the financial statements are fairly presented, in accordance with generally accepted accounting principles, and thus implying full disclosure. As I read the annual report, I came across a footnote which I simply did not understand. The footnote related to taxes and I don't claim

Readers with comments or questions are encouraged to contact the authors via email. 
to be a tax expert but I do claim to have a pretty good basic understanding of taxes. After reading the footnote several times and being completely baffled, I went to visit a professor named Richard Johnson who is a CPA, an attorney, a truly brilliant person, and whom I consider to be a genuine tax expert.

Rick read the footnote over several times and confessed that he did not understand it. He told me that he had an uncle who worked for Con Agra in the accounting function. Rick offered to call his uncle and ask him what the footnote meant. I asked Rick to do so. A few days later, I visited Rick in his office and asked him if he had called his uncle. Rick said that he had. I asked him what his uncle had said. Rick told me that his uncle had said, "It's none of your damn business!" I must assume that Con Agra was somehow trying to disclose what they were required to disclose but for some reason did not want the general public, a non-tax accounting professor, a genuine tax expert, nor even a relative to know what it really meant. Coopers \& Lybrand had given the entire financial statements their stamp of approval even though they were probably fully aware that they were incomprehensible to anyone who would read them.

\subsection{That Was Then (1978); This Is Now}

As information about Enron debacle began to unfold, we read an article that appeared in the November 5, 2001 Wall Street Journal titled, "Andersen Faces Scrutiny on Clarity of Enron Disclosures." That article discusses how parts of the Enron annual report are "indecipherable." The article quotes Karen Denne, a spokesperson for Enron. In one part, she states that if anyone does not understand the financial statements all they need to do is ask. Judging from other statements made in the article which are attributed to Ms. Denne, we must assume that if we were to ask, her answer might be very similar to the response received from Rick Johnson's uncle in the Con Agra case. In another part of the article she tries to defend the quality of the financial statements by saying, "They comply with reporting requirements." Ms. Denne does not seem to seem to recall the Continental Vending case. She then continues with this appalling statement, “...investors who didn't understand the transactions didn't have to buy Enron stock." Wow, what a way to justify a lack of full disclosure!!! In the same article, Douglas Carmichael, an accounting professor at Baruch College in New York, said of the disclosures, "The raw numbers may all be there. But any objective person would be hard pressed to understand the effects of these disclosures on the financial statements." Although Professor Carmichael's comment is aimed specifically at Enron, it could just as well be aimed at Con Agra (and perhaps many more companies) as well.

Exactly one week later, on November 12, 2001, there was another article on Enron titled, "Basic Principle of Accounting Tripped Enron." The article began by stating, "What could Arthur Andersen have done to protect the investing public from Enron? Brushing up on a basic accounting textbook might have helped..." The article states that portions of Enron's accounting practices amounted to violations of elementary accounting principles. The article then quotes former SEC Chief Accountant, Lynn Turner who asks, "How did both partners and the manager on this audit miss this simple Accounting 101 rule?" Since it was so simple, these authors can only assume that it was intentional rather than erroneous. We hope that the fact that Enron paid Andersen \$25 million for the audit and \$27 million for other services did not have an impact on Andersen auditors' judgment. Unfortunately, these authors' suspicious minds make us suspect that all of those dollars actually did have an impact.

Exactly one month after the first Enron article referenced above, another Enron article appeared in the December 5, 2001 Wall Street Journal. That article stated, "The company (Enron) hired legions of lawyers and accountants to help it meet the letter of federal securities laws while trampling on the intent of those laws. It became adept at giving technically correct answers rather than simply honest ones." Again, it appears that Enron people did not recall Continental Vending and thus repeated the same mistakes. We accountants must resist any temptation to become involved in such fraudulent financial reporting. Fraudulent financial reporting is of no value in our society. We need to be the protectors of financial reporting integrity or this profession is of no value in our society.

\subsection{Conclusion}

Enron auditors seem to have failed to learn from the Continental Vending case. If all auditors fail to learn from the Enron case, we are likely to see a case similar to Enron occur again in about 2040, or even sooner. Let's not let it happen! 
A table comparing Enron and Continental Vending:

\begin{tabular}{|c|c|}
\hline \multicolumn{2}{|c|}{ Enron and Continental Vending: A Comparison } \\
\hline Continental Vending & Enron \\
\hline \multicolumn{2}{|c|}{ Criminal charges } \\
\hline $\begin{array}{l}\text { Continental Vending was the first case in which auditors were } \\
\text { charged criminally for a failed audit. }\end{array}$ & $\begin{array}{l}\text { Enron is the first case in which an accounting firm was indicted on } \\
\text { criminal charges. }\end{array}$ \\
\hline \multicolumn{2}{|c|}{ What was the issue? } \\
\hline They overstated the Owners' Equity. & They understated liabilities and thus overstated the Owners' Equity. \\
\hline \multicolumn{2}{|c|}{ How did they do it? } \\
\hline $\begin{array}{l}\text { In Continental Vending, the issue was a receivable between } \\
\text { Continental Vending and Valley Mortgage which was collateralized } \\
\text { by Continental Vending stock. Both Continental and Valley had the } \\
\text { same owners. When Continental stock decreased in value, the } \\
\text { receivable became worthless. }\end{array}$ & $\begin{array}{l}\text { In Enron, the issue is Special Purpose Entities which were essentially } \\
\text { all owned by Enron but not included in the Enron financial } \\
\text { statements. There were liabilities in the Special Purpose Entities } \\
\text { which should have been reported by Enron but were not. }\end{array}$ \\
\hline \multicolumn{2}{|c|}{ What is the accounting term for that? } \\
\hline $\begin{array}{l}\text { The accounting profession created a new term for it. It is called } \\
\text { "Related Party Transactions." }\end{array}$ & Again, we are talking about "Related Party Transactions." \\
\hline \multicolumn{2}{|c|}{ Did the auditor Know? } \\
\hline $\begin{array}{l}\text { The Continental Vending auditors never claimed to be unaware of } \\
\text { the accounting methods being employed. }\end{array}$ & $\begin{array}{l}\text { The Enron auditors never have claimed to have been unaware of the } \\
\text { accounting methods being employed. }\end{array}$ \\
\hline \multicolumn{2}{|c|}{ What about full disclosure? } \\
\hline $\begin{array}{l}\text { The judge in this case held that the profession must be held to a } \\
\text { higher standard than GAAP....The message was that auditors should } \\
\text { evaluate the probable effect of disclosures on stockholders' } \\
\text { investment decisions, and if the disclosures are likely to affect such } \\
\text { decisions, disclosure is appropriate, regardless of GAAP's } \\
\text { requirements. }\end{array}$ & $\begin{array}{l}\text { It appears that the court will state essentially the same things as it } \\
\text { said in Continental Vending. The profession is already reacting to } \\
\text { implement standards which would have required disclosure by Enron } \\
\text { had they been effective months ago. }\end{array}$ \\
\hline \multicolumn{2}{|c|}{ History of stock prices of the companies } \\
\hline 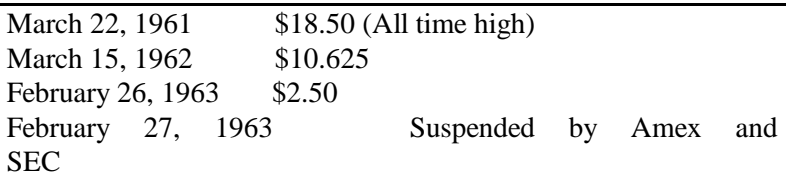 & $\begin{array}{ll}\text { August 31, 2000 } & \$ 84.88 \\
\text { August 31, 2001 } & \$ 34.99 \\
\text { November 30, 2001 } & \$ 0.26 \\
\text { July 31, 2002 } & \$ 0.11 \text { (over the counter) }\end{array}$ \\
\hline \multicolumn{2}{|c|}{ Stock prices after disclosure of irregularities } \\
\hline $\begin{array}{l}\text { Continental Vending stock which had a market value of } \$ 2,978,000 \\
\text { on February } 15,1963 \text { was pledged as collateral for the Valley } \\
\text { Commercial Corporation loan. That stock dropped in value to } \\
\$ 395,000 \text { ten days later and two days before the government } \\
\text { padlocked the plant and the American Stock Exchange suspended } \\
\text { trading of Continental stock. (Rittenberg \& Schwieger, Auditing, } \\
\text { page 152) }\end{array}$ & $\begin{array}{l}\text { It is well documented that Enron stock suffered a dramatic and } \\
\text { sudden decrease from its historic high of about } \$ 90 \text { per share to } \$ .25 \\
\text { per share just before the bankruptcy was announced. }\end{array}$ \\
\hline \multicolumn{2}{|c|}{ The adequacy of footnote disclosures } \\
\hline $\begin{array}{l}\text { The judge in the Continental Vending case said, "The jury could } \\
\text { reasonably have wondered how accountants who were really seeking } \\
\text { to tell the truth could have constructed a footnote so well designed to } \\
\text { conceal the shocking facts." (Rittenberg \& Schwieger, Auditing, } \\
\text { page 153) }\end{array}$ & $\begin{array}{l}\text { On November 5, 2001, the Wall Street Journal reported that, "Many } \\
\text { Wall Street analysts, including die-hard Enron bulls, long have } \\
\text { grumbled that parts of Enron's financial statements are } \\
\text { indecipherable." }\end{array}$ \\
\hline
\end{tabular}

Table continued on next page. 
Table Continued:

Misleading comments made by lead executive prior to disclosure or irregularities

Harold Roth, President and Chairman:

Wall Street Journal, February 21, 1962

Kenneth Lay: CEO and Chairman

Business 2.0: March, 2002

"I have every reason to believe that 1962 will continue to show as great improvement (as the year before), and will be the first of many years of spectacular growth."

"Our performance has never been stronger; our business model has never been more robust; our growth has never been more certain..." (From Kenneth Lay, in an e-mail to all employees, August 14, 2001).

Regarding the first four months of 1962: "Our sales have been going according to our plans, our earnings have been holding up well."

Significance of the client to the auditor

The difference here is striking. Continental was not the kind of client whose size would give it leverage to bully a great accounting firm. It was even reported that Continental had become a considerable headache to Lybrand (Journal of Accountancy,

February, 1970, page 67).

Enron was a significant client. It was the seventh largest corporation in the world and the second largest client of Andersen. 